Hischarge; evening temperature normal. A probewas allowed to ferret its way through softened tissue for about two inches backwards, suddenly it dropped into a large cavity, and pus welled up in abundance, the passage was enlarged with dressing forceps, and this second cavity drained and dressed with carbolic oil. $-18 \mathrm{oh}$ : Since last date syringed through drainage tube with Condy's fluid; tube expelled from a shallow dimpled recess representing the wound.24th : Patient joined regiment October, 1891, in the best of health.

The total amountof matter expelled was about three pints. Gloucester.road, N.W.

\section{NOMA AS A COMPLICATION OF ENTERIC FEVER.} By John Donald, M.A., M.B.

As nome is a rare complication of this disease, a fow remarks on two cases in which ib occurred may prove interesting,

0n Sepo. 9th, 1891, I began to attead two children, Lizzie $\mathrm{P}_{-}$, aged four, and Jane $\mathrm{B} \longrightarrow$, aged eight, both of whom were found to be suffering from enteric fever. They had been ailing for about a week, Lizzie 3 - having been taken ill a day or two before her sister. The symptioms all through were much alike in the two cases, the nervous symptoms predominating. There was marked prostration, and great restlessness and delirium of a low type. The temperature varied from $102.5^{\circ}$ to $104^{\circ}$, and the pulse ranged from 110 to 130 . Diarrhca was present in both, bao persisted longer, and was with difficulty controlled in the elder. No rash could be found in either case, and there were no lung complications. The tongue was dry and cracked, and there were abundant sordes on the lips and teeth. About Sept. 13th the pulse became very weak, and there was a tendency to heart failure. This was combated with stimulants, given freely in the form of diluted brandy; but it was with difficulty that they were roused from their lethargic condition to partake of this and other necessary nourshiment. With the persistence of such a low "typhoid" state, the prognosis was very bad, and when noma set in their recovery was practically hopeless. On Sept. $16 \mathrm{th}$ a hard swelling was felt in the right cheek of the younger, which gradually increased in size and got tense and glazed externally. Ulceration took place internally, but the disease did not follow the rapid course that sometimes occurs. The child remained in a comatose condition till Sept. $20 \mathrm{tb}$, when she died, before perforation of the cheek had taken place. On Sapt. 18th noma was found in the right cheek of the elder girl, and pursued a similar course, till she died, in the same comstose condition, on Sept. $22 n d$.

Noma as a rule follows on some debilitating disease, but for its development the presence of foul air and bad sanitary arrangements are usually regarded as essential. Here the conditions were present, as the cases occurred in a small, badly ventilated house in a narrow street. In another case, which I saw during convalescence from measles, where a fatal issue likewise took place, the house was permeated with bad smells. It is probable that the microorganisms supposed to canse this disease gain entrance to the tissues lorally, as it is difficult to conceive how they should select such a site, if they were introduced into the circulation in the first place. In the cases of enteric fever referred to it is easy to comprehend that the state of the mucous membrane of the mouth was such as to furnish a suitable spot for the inroad of disease germs. In regard to local treatment, no violent measures were resorted to, as the low, practically hopeless condition of the patients did not seem to warrant any such. So much of the ulcerated tissue as could be scraped easily away was removed, and antiseptic washes were freely employed to cleanse the mouth. Glasgow.

AN UNUSUAL CASE OF TWINS.

By GEORGE JoInN O'REILIY, L.K.Q.C.P.I., \&c.

I ATTENDED Mis. $\mathrm{K}$ - on the 8 th ult. in her fourth confinement. There was nothing unusual to note in the history of this pregnarcy, except that she complained of not having felt the movements of the child for some ten days before delivery. During the labour I felt satisfied that I noticed the movements of the foetus during examination. When delivery was effected an eight months' embryo presented itself in a macerated condition, the cuticle peeling of in several places. When I grasped the uterus to express the placenta I noticed that organ was larger than usual after delivery, and that the surface was lumpy and uneven. I examined per vaginam, but could noo detect anything abnormal. I gave a dose of ergot and waited results. Labour pains soon set in, and became stronger every minute, and on again examining I found the head of a second foetus presenting. After a short time a living child was expelled, and as it was very feeble I had it wrapped in cotton wool, and kept near the fire. The placenta came away within a short time. There was little or no bremorrhage. The case terminated normally. The mother made a good recovery and was up on the eleventh day, I hardly expected the child to live, and did not weigh it at birth. However, the infant has lived, and takes its nourishment well, and seems to thrive. On the twentyfirst day it weighed with cotton wool and shawl $3 \mathrm{lb} .1 \mathrm{oz}$ A week afterwards it wejghed $3 \mathrm{lb} .50 \mathrm{z}$. There was only one placenta; the cords of both were attached within a short distance of each other ; two-thirds of the placenta were of a livid red colour and of firm consistence, and to this portion the firstborn was attached. The cord was three times as thick as that of the living child, the other one-third portion of placenta was healthy. There was a distinct line of demareation between the two portions. The stillborn child was unfortunately not weighed, but $I$ should say it was from 4 to $51 b$.

Highgate, $N$.

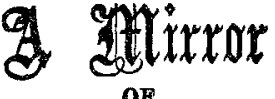

\section{HOS P T A L P ACTICE, BRITISH AND FOREIGN.}

Nulla autem est alia pro certo noscendi via, nisi quamplurimas eb mor. borum et dissectionum historias, tum aliorum tum proprias collectas habere, et inter se comparare.-MORGAGNI De Sed. et Cous. Morb. aabere, et inter se

\section{SEAMEN'S HOSPITAL, GREENWICH.}

NOTES OF TWO FATAL CASES OF INFLUENZA.

(Under the care of Dr. JOHN ANDERSON, C.I.E.)

THESE two cases are specially interesting, as showing the mode of death in cases of influenza, which are not fatal in consequence of bronchitis, pneumonia, or some other similar complications. Both patients died from syncope due to cardiac failure induced by the influenza alone, and in both no cardiac lesion, either of the walls or of the valves, existed. In the second case the histological examination, showing that the heart structure was quite normal, was made by Mr. Hewlett, M.B. Lond., Demonstrator of Bacteriology in King's College. For the report of these cases we are indebted to Dr. M. H. Spencer.

CASE 1.-A. C—, a sailor, aged thirty.five, was admitted into the hospital on Jan. 11th, 1892. He was taken ill eleven days before admission with pains "all over him," accompanied by some cough, but had not kept his bed. When he was admitted the temperature was $101^{\circ} 6^{\circ}$; respiration 42 ; pulse 118. Auscultation revealed only sibilant rhonchns over the greater part of the lungs, with sorre small râles, most marked over the left lower lobe. No impairment of resonance anywhere over the lungs. The heart sounds were normal. The urine was free from albumen. There was a good deal of cough, with profuse watery expectoration. Ammonia mixture ordered every two hours. For the next two days the patient remained in much the same condition, the temperature still continuing high, ranging between $102 \cdot 4^{\circ}$ and $103.4^{\circ}$ at night, and falling to between $99^{\circ}$ and $100^{\circ}$ in the morning. The dyspncez, however, had diminished. At midnight on Jan. 14th the pulse for the first time showed signs of failure. Stimulant was freely given, and quinine and digitalis were ordered. On the 15 th his condition was much worse. The pulse was 140 , and although the bronchial signs over the lungs had diminished 